\title{
Both Hepatic Lipogenesis and Beta-Oxidation are Altered in Offspring of Mothers Fed a High-Fat Diet in the First Two Generations (F1 and F2)
}

\author{
La Lipogénesis Hepática y la Beta-Oxidación están Alteradas en las Crías de Madres \\ Alimentadas con una Dieta Alta en Grasas en las Dos Primeras Generaciones (F1 y F2)
}

Wilian Rodrigues Lannes*; Andressa Cabral de Miranda*; Vanessa de Souza-Mello*; Sandra Barbosa-da-Silva*; Marcia Barbosa Aguila* \& Carlos Alberto Mandarim-de-Lacerda*

LANNES, W. R.; MIRANDA, A. C.; SOUZA-MELLO, V.; BARBOSA-DA-SILVA, S.; AGUILA, M. B. \& MANDARIM-DELACERDA, C. A. Both hepatic lipogenesis and beta-oxidation are altered in offspring of mothers fed a high-fat diet in the first two generations (F1 and F2). Int. J. Morphol., 33(4):1510-1517, 2015.

SUMMARY: The high fat (HF) fed mothers may program susceptibility in offspring to chronic diseases and affect subsequent generations. The present study evaluated the liver structure in adulthood, focusing on the F1 and F2 generations. Females C57BL/6 (F0) were fed standard chow (SC) or HF diet ( 8 weeks) prior to mating and during the gestation and lactation to provide the F1 generation (SC-F1 and HF-F1). All other mothers and offspring fed SC. At 3 months old, F1 females were mated to produce the F2 generation (SCF2 and HF-F2). The liver was kept in several fragments and prepared for histological analysis or frozen for biochemical and molecular analyzes. The F1 and F2 offspring were studied at 3 months old. HF-F1 had higher body mass (BM) compared to SC-F1 (P= 0.001), but not HF-F2 compared to SC-F2. HF-F1 had glucose intolerance when compared to SC-F1, but not HF-F2 compared to SC-F2. HF-F1 (P= 0.009) and HF-F2 $(\mathrm{P}=0.03)$ showed hyperinsulinemia compared to their counterparts. Both groups HF-F1 and HF-F2 showed more steatosis than the SC counterparts (F1 and F2, P<0.0001). HF-F1 showed increased expression of PPAR-gamma and SREBP1-c compared to SC-F1 ( $\mathrm{P}=0.01)$. HF-F2 showed increased PPAR-gamma expression compared to SC-F2 $(\mathrm{P}=0.04)$. In conclusion, HF-fed mother impairs both lipogenesis and beta-oxidation pathways in F1 through upregulation of PPAR-gamma and downregulation of PPAR-alpha. In F2, the only lipogenesis is enhanced, but it causes a disrupted PPAR balance, favoring the hepatic lipid accumulation and impaired metabolism in these animals that were not directly exposed to the maternal HF intake.

KEY WORDS: High-fat diet; Hepatic lipogenesis; Beta-oxidation; Maternal obesity; Offspring.

\section{INTRODUCTION}

A growing body of evidence has associated maternal nutrition with altered offspring metabolism (Alfaradhi et al., 2014; Ornellas et al., 2015). A high fat (HF) fed mothers favors the early onset of obesity and its comorbidities in the offspring even when there is balanced nutrition in their postweaning life (Gregorio et al., 2010). Hyperinsulinemia seems to mediate this metabolic disruption as it is able to transpose placenta and the liver, as a central organ of metabolism, has emerged as a potent target to excessive lipids during intrauterine life (Yessoufou \& Moutairou, 2011).

Insulin resistance plays a pivotal role in NAFLD genesis as it stimulates lipolysis in white adipose tissue, augmenting the hepatic input of free fatty acids and impairs beta-oxidation in the liver (Angulo, 2007). Peroxisome proliferator-activated receptors (PPARs) are transcription factors responsible for the transcription of genes involved in hepatic beta-oxidation and lipogenesis (Wahli \& Michalik, 2012). HF-fed mothers cause disrupted PPAR balance in the first generation offspring, favoring the high expression of PPAR-gamma (lipogenic factor) concomitant to decreased expression of PPAR-alpha, essential to mitochondrial betaoxidation (Magliano et al., 2013).

Hepatic impairments have been described in both newborn mice (Bringhenti et al., 2015) and in adult mice (Alfaradhi et al.). However, little attention is given to a possible intergenerational effect of maternal HF diet on liver 
structure and function. The present study aimed to verify whether the hepatic outcome from pre-gestational and perinatal maternal obesity persists into the second generation, focusing on the disruption of the main metabolic pathways related to NAFLD onset.

\section{MATERIAL AND METHOD}

Animals and diets. The Animal Ethics Committee of the State University of Rio de Janeiro approved the study with the protocol no. CEUA/017/2013. All procedures followed strictly the guidelines for experimentation with animals (NIH Publication no. 85-23, revised 1996). The animals were housed under controlled conditions of temperature $\left(21 \pm 2^{\circ} \mathrm{C}\right)$ and humidity $(60 \pm 10 \%)$ in a 12 -h light/dark cycle, and had free access to food and water.

Initially, ten virgin C57BL/6 females with onemonth-old were divided into two groups according to the dietary lipid content: SC (standard chow group) and HF (high-fat group). The SC (19\% protein, 64\% carbohydrate, $17 \%$ fat) and the HF diet (19\% protein, $32 \%$ carbohydrates, $49 \%$ fat) were manufactured by PragSolutions (Jau, SP, Brazil) following the recommendations of the AIN-93G (Reeves et al., 1993) and offered since two months before mating until the end of lactation. Those females were the mothers F0.

Offspring of the mothers F0 was randomly reduced to six pups in their litters (with a 1:1 sex ratio). All offspring, no matter what food the mother had access were weaned onto the SC diet at postnatal day 21. The groups SC-F1 and HF-F1 were formed by randomly keeping one male per litter $(n=5)$.

Females of the SC-F1 and HF-F1 generations, ever fed SC, were keep at 3 mo old and mated with a male bred outside the experiment, without any dietary manipulation, to produce F2 offspring, and F2 litters followed the same protocol as F1 litters until weaning, i.e., all offspring of F1 and F2 generations were fed SC, but they were labeled according to the mother F0:

a) SC-F1: male offspring of the first generation of the SCF0 mothers;

b) HF-F1: male offspring of the first generation of the HFF0 mothers;

c) SC-F2: male offspring of the second generation of the SC-F0 mothers;

d) HF-F2: male offspring of the second generation of the HF-F0 mothers.
Mothers. The body mass (BM) was measured weekly. After mating, the $\mathrm{BM}$ gain was assessed considering the $\mathrm{BM}$ before mating. Two days before mating, the oral glucose tolerance test was performed (as described below).

\section{Offspring}

Glucose metabolism. Oral glucose tolerance test (OGTT) was performed after $6 \mathrm{~h}$ fasting. Glucose $(1 \mathrm{~g} / \mathrm{kg})$ was administered by orogastric gavage, and blood samples were collected in the caudal vein before and at 15, 30, 60, and 120 min after glucose overload. Glucose levels were measured using a glucometer (Accu-Chek, Roche Diagnostics, Germany). The analysis was based on the area under the curve (AUC) calculated in the interval 0 to $120 \mathrm{~min}$ (Prism version 6.05 for Windows, GraphPad software, La Jolla, CA, USA).

Body mass and euthanasia. F1 and F2 offspring had their BM measured weekly and their food and energy intakes measured daily until 3-mo-old, when the animals were food deprived for $6 \mathrm{~h}$ and anesthetized in the $\mathrm{CO}_{2}$ chamber and blood was collected by cardiac puncture.

Metabolic parameters. Plasma concentrations of insulin were measured using enzyme immunoassay (\# EZMADP$60 \mathrm{~K}$, insulin Cat, Millipore, Missouri kit) with the TP-Reader ELX800 (BioTek Instruments, USA). Total cholesterol, triacylglycerol and alanine aminotransferase (ALT) were measured using a colorimetric kinetic method (Bioclin System II, Quibasa, Belo Horizonte, MG, Brazil).

Liver structure. Liver fragments obtained from all parts of the organ were prepared for light microscopy. Briefly, fragments were fixed in $4 \%$ formaldehyde for $48 \mathrm{~h}$ at room temperature and then embedded in Paraplast plus (SigmaAldrich Co., St. Louis, MO, USA), sectioned at $5 \mu \mathrm{m}$ of thickness, and sections were stained with hematoxylin and eosin. Digital images were obtained in a BX51 microscope (Olympus Co., Tokyo, Japan), and an Infinity 1-5c camera (Lumenera Co., Ottawa, Canada). The volume density of steatosis ( $\mathrm{Vv}$ [steatosis]) was assessed by point counting (in a 36 points test-system) on at least ten random fields per animal (Aguila et al., 2003; Catta-Preta et al., 2011).

Hepatic triacylglycerol. Fifty mg of liver was placed in Eppendorf containing $1 \mathrm{ml}$ of isopropyl alcohol, and after homogenate was macerated and then placed in the sonicator (Model LB-130 PB Labormetric, Miami, FL, USA) for $20 \mathrm{~s}$. It was subsequently taken to a refrigerated centrifuge at $4{ }^{\circ} \mathrm{C}$ for $10 \mathrm{~min}$ at $4,700 \mathrm{RPM}$. After this procedure, $5 \mu \mathrm{L}$ of the supernatant was pipetted and mixed with the reagent kit and quantified in a spectrophotometer (Bioclin, Quibasa, Belo Horizonte, MG, Brazil). 
LANNES, W. R.; MIRANDA, A. C.; SOUZA-MELLO, V.; BARBOSA-DA-SILVA, S.; AGUILA, M. B. \& MANDARIM-DE-LACERDA, C. A. Both hepatic lipogenesis and beta-oxidation are altered in offspring of mothers fed a high-fat diet in the first two generations (F1 and F2). Int. J. Morphol., 33(4):1510-1517, 2015.

Western blot analysis. Protein extracts were isolated from homogenized liver tissues and the total proteins were evaluated using western blotting, in accordance with the following steps: Initially, around $100 \mathrm{mg}$ of frozen liver were homogenized in a buffer containing protease inhibitors. The homogenates were centrifuged at $4{ }^{\circ} \mathrm{C}$, the supernatants were collected, and the total protein was determined using a BCA protein assay kit (Thermo Scientific, Rockford, IL, USA). Equal quantities of total protein were separated using polyacrylamide gel electrophoresis. Then, the membrane was blocked by incubation with $6 \%$ (wt/vol) nonfat dry milk in Tris-buffered saline [20 mmol/L Tris/HCl (pH 7.4) and $500 \mathrm{mmol} / \mathrm{L} \mathrm{NaCl}]$ and sequentially incubated overnight at $4{ }^{\circ} \mathrm{C}$ with the following primary antibodies: to analyze the hepatic lipogenesis (SREBP1-c 68kDa; SC-367) (PPAR-gamma 67kDa, SC-7273). To analyze hepatic beta-oxidation (PPAR-alpha $55 \mathrm{kDa}$, SC9000); The membranes were also incubated with anti-b-actin (monoclonal antibody; 43 kDa; sc-81178; 1:1000; Santa Cruz Biotechnology). After incubation, the membranes were washed with TBS-T and incubated with secondary antibodies for $1 \mathrm{~h}$ at room temperature. The membrane was developed using ECL Western blotting detection reagents, and images of the blot were obtained from Bio-Rad image ChemiDoc XRS Molecular Systems (Bio-Rad, Hercules, CA, USA). The chemiluminescent intensity of the bands was quantified using ImageJ software, version 1:49 (NIH imagej.nih.gov/ij, USA).

Statistical analysis. Data are expressed as mean and the associated standard deviation. The sample (n) refers to the number of litters per group (only one male per litter was kept to form the groups). Data were analyzed using one-way analysis of variance followed by the posthoc test of Holm-Sidak. Twoway ANOVA was performed considering the factors: a) maternal diet (in F0), and b) the offspring generation. In all cases, a
P-value $<0.05$ was considered statistically significant. (Prism version 6.05 for Windows, GraphPad software, La Jolla, CA, USA).

\section{RESULTS}

\section{Mothers}

Body mass. Mothers started the experiment without showing any significant difference in BM. During the pre-mating period (the first eight weeks of the experiment), the HF mothers showed increased $\mathrm{BM}(+6 \%)$ when compared to the SC mothers $(\mathrm{P}=0.01)$. However, the mothers of the HF-F1 generation, used to produce HF-F2 offspring, have no significant difference in $\mathrm{BM}$ during the pre-mating period compared to SC-F1 mothers (Table I).

Oral glucose tolerance test- OGTT. OGTT was carried out in the immediate pre-pregnancy period to avoid stress during the pregnancy. The HF-0 group had a higher AUC, showing impaired glucose tolerance compared to the $\mathrm{SC}$ group $(\mathrm{P}=$ 0.0001). However, the HF-F1 mothers showed no significant difference in the OGTT during the pre-mating period in comparison with the SC-F1 mothers (Table I).

\section{Offspring}

Body mass. The HF-F1 offspring showed greater BM than the SC-F1 offspring (since weaning until 3-mo-old) $(\mathrm{P}=0.001)$. As the animals began to consume $\mathrm{SC}$ at weaning, this finding is an effect of maternal nutrition. However, HF-F2 offspring showed no significant difference in BM compared to the SCF2 offspring (Table I).

Table I. Data presented as means \pm standard deviation. Means $\mathrm{P}<0.05$ ( $\dagger$ ), when compared to the standard chow (SC) group of the same generation (one way ANOVA and posthoc test of Holm-Sidak).

\begin{tabular}{llcccc}
\hline Data & & SC-F1 & HF-F 1 & SC-F2 & HF-2 \\
\hline Mothers & Body mass (g) & $20.0 \pm 0.2$ & $21.4 \pm 0.4 \dagger$ & $19.5 \pm 0.3$ & $20.4 \pm 0.5$ \\
& OGTT (AU, auc) & $705.5 \pm 32.0$ & $990.6 \pm 12.5 \dagger$ & $712.1 \pm 23.2$ & $730.8 \pm 48.1$ \\
Offspring & & & & \\
& Body & $25.2 \pm 0.20$ & $28.3 \pm 0.50 \dagger$ & $25.9 \pm 0.18$ & $24.8 \pm 0.77$ \\
& Mass (g) & $125.3 \pm 3.27$ & $172.0 \pm 8.81 \dagger$ & $111.2 \pm 2.69$ & $114.8 \pm 1.61$ \\
& Total cholesterol (mg/dL) & $84.9 \pm 1.77$ & $96.8 \pm 1.03 \dagger$ & $86.8 \pm 2.05$ & $88.0 \pm 1.66$ \\
& Triacylglycerol (mg/dL) & $3.1 \pm 0.43$ & $5.4 \pm 0.52 \dagger$ & $3.6 \pm 0.33$ & $4.9 \pm 0.37 \dagger$ \\
& Insulin (IU/L) & & & & \\
& Liver & $0.5 \pm 0.02$ & $0.6 \pm 0.01 \dagger$ & $0.4 \pm 0.02$ & $0.5 \pm 0.02$ \\
& Mass (g) & $37.6 \pm 0.92$ & $50.6 \pm 2.60 \dagger$ & $37.4 \pm 2.11$ & $37.0 \pm 3.39$ \\
& ALT (IU/L) & $1.4 \pm 0.11$ & $1.9 \pm 0.11 \dagger$ & $2.0 \pm 0.19$ & $2.3 \pm 0.10$ \\
\hline
\end{tabular}

Groups: Only original mothers (F0) fed standard chow (SC) or high-fat diet (HF), the subsequent mothers fed standard chow. Offspring of the first (F1) or second generation (F2) received the label according to their original mothers.

Abbreviations: $\mathrm{ALT}=$ alanine aminotransferase; $\mathrm{AU}=$ arbitrary units; auc= area under the curve; $\mathrm{OGTT}=$ oral glucose tolerance test; $\mathrm{IU}=$ international units. 
LANNES, W. R.; MIRANDA, A. C.; SOUZA-MELLO, V.; BARBOSA-DA-SILVA, S.; AGUILA, M. B. \& MANDARIM-DE-LACERDA, C. A. Both hepatic lipogenesis and beta-oxidation are altered in offspring of mothers fed a high-fat diet in the first two generations (F1 and F2). Int. J. Morphol., 33(4):1510-1517, 2015.


Fig. 1. Oral glucose tolerance test. The values are the means and their standard deviations; one way ANOVA and posthoc test of Holm-Sidak. Groups: Original mothers (F0) fed standard chow (SC) or high-fat diet (HF) and subsequent mothers fed standard chow. Offspring of the first (F1) or second generation (F2) received the label according to their original mothers.

Glucose metabolism. The HF-F1 offspring had hyperinsulinemia compared to the SC-F1 offspring $(\mathrm{P}=$ 0.009), and the HF-F2 offspring had hyperinsulinemia compared to the SC-F2 offspring $(\mathrm{P}=0.03)$ (Table I).
The OGTT was greater in the HF-F1 offspring (+8.6\%) compared to the SC-F1 offspring $(\mathrm{P}=0.006)$, characterizing glucose intolerance. However, no significant difference in the OGTT was found comparing the offspring HF-F2 and SC-F2 (Fig. 1).
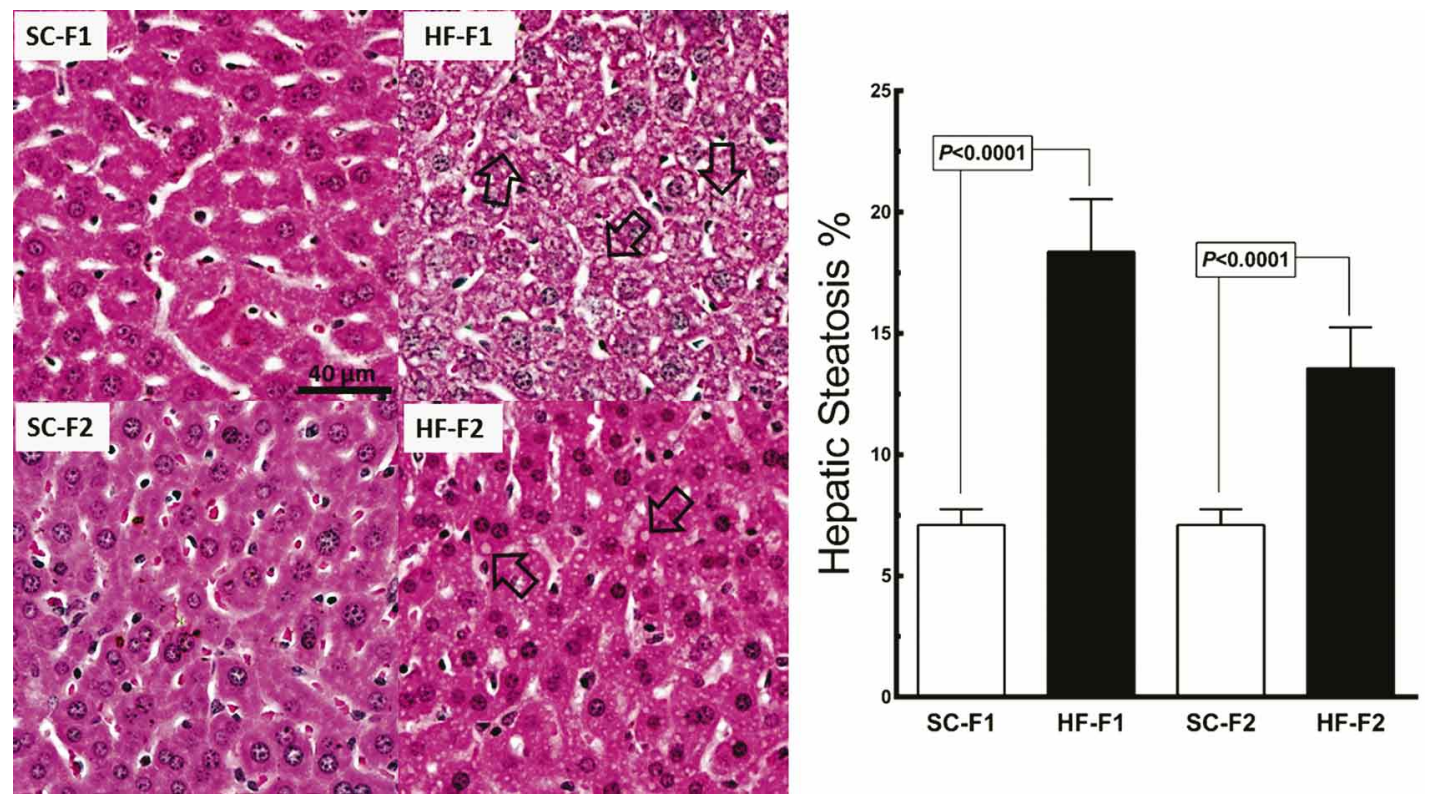

Fig. 2. Hepatic steatosis. The values are the means and their standard deviations; one way ANOVA and posthoc test of Holm-Sidak. Groups: Original mothers (F0) fed standard chow (SC) or high-fat diet (HF) and subsequent mothers fed standard chow. Offspring of the first $(\mathrm{F} 1)$ or second generation $(\mathrm{F} 2)$ received the label according to their original mothers. 
Plasma lipids. The HF-F1 offspring showed a significant increase in triacylglycerol $(+14 \%)$ and total cholesterol $(+37 \%)$ levels compared to the SC-F1 offspring $(\mathrm{P}<0.05)$. On the other hand, no difference was seen (total cholesterol and triacylglycerol) comparing the offspring HF-F2 and SC-F2 (Table I).

Lipogenesis and hepatic steatosis. The mass of the liver was $20 \%$ greater in the HF-F1 offspring than in the SC-F1 offspring $(\mathrm{P}=0.006)$, but the mass of the liver was not different comparing the groups HF-F2 and SC-F2.

The triacylglycerol content in the liver was $30 \%$ higher in the HF-F1 offspring than in the SC-F1 offspring ( $\mathrm{P}=0.03)$, but no difference was found in the triacylglycerol content in the liver comparing the offspring HF-F2 and SC-F2 (Table I).
The volume density of the hepatic steatosis was $180 \%$ greater in the HF-F1 offspring compared to the SC-F1 offspring $(\mathrm{P}<0.0001)$, and was $86 \%$ greater in the HF-F2 offspring compared to the SC-F2 offspring $(\mathrm{P}<0.0001)$ (Fig. 2).

The ALT enzyme, a marker of liver injury, was elevated in the HF-F1 offspring compared to the SC-F1 offspring ( $\mathrm{P}=0.001)$, but no difference was found comparing the offspring HF-F2 and SC-F2 (Table I).

Figure 3 shows protein expressions in the liver. In the first generation, the HF-F1 offspring showed increased liver expression of both PPAR-gamma and SREBP1-c (associated with lipogenesis) than the SC-F1 offspring ( $\mathrm{P}=$ 0.01). The HF-F1 offspring showed diminished liver expression of PPAR-alpha (associated with beta-oxidation)

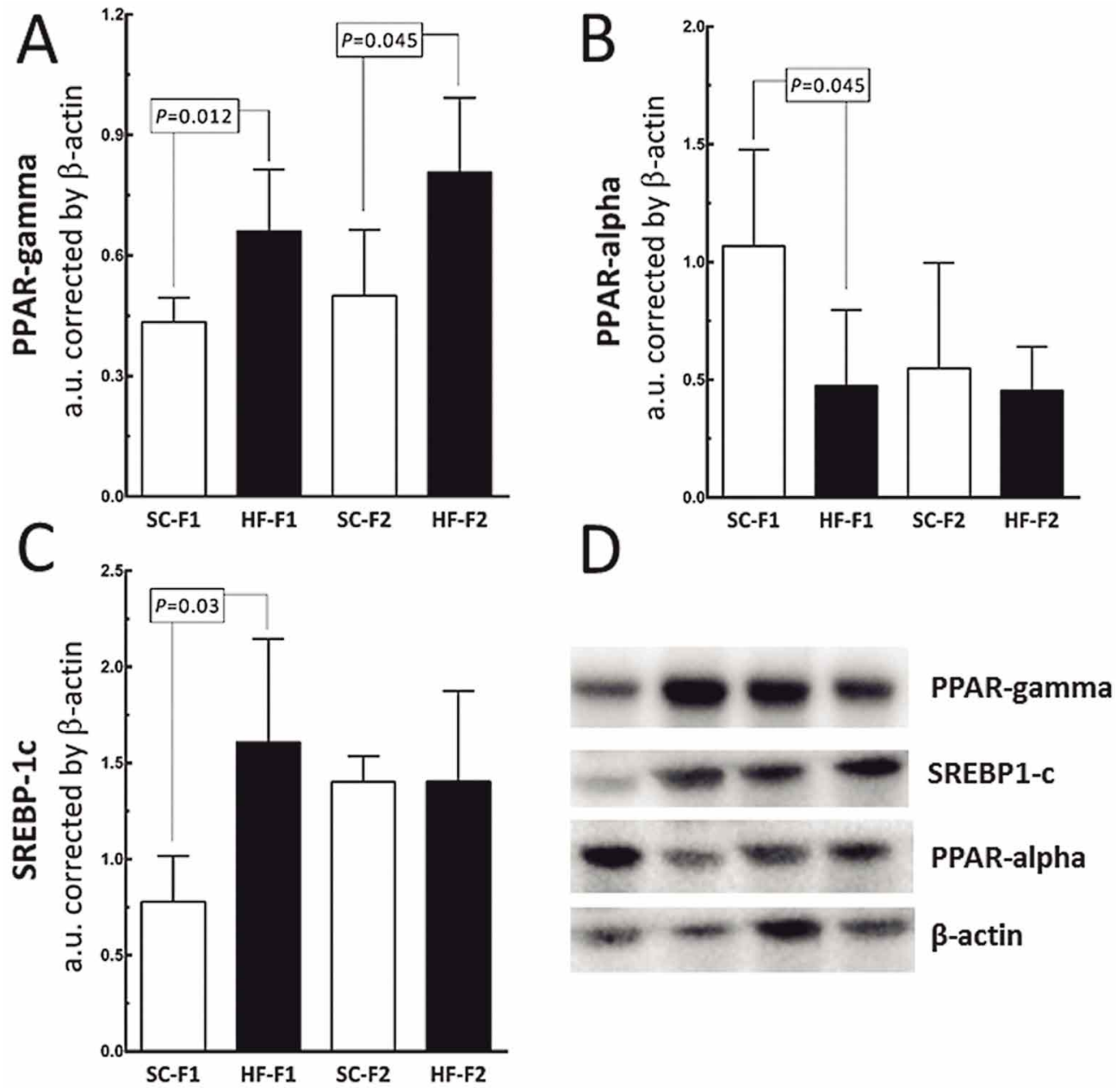

Fig. 3. Protein expression in the liver. The values are the means and their standard deviations; one way ANOVA and posthoc test of Holm-Sidak. Groups: Original mothers (F0) fed standard chow (SC) or high-fat diet (HF) and subsequent mothers fed standard chow. Offspring of the first (F1) or second generation (F2) received the label according to their original mothers. A) PPAR-gamma; B) PPAR-alpha; C) SREBP-1c; D) representative bands in the sequence of the groups: SC-F1, HF-F1, SCF2 and HF-F2. 
than the $\mathrm{SC}-\mathrm{F} 1$ offspring $(\mathrm{P}=0.04)$. In the second generation, the HF-F2 offspring showed increased liver expression of PPAR-gamma compared to the SC-F2 offspring $(\mathrm{P}=0.04)$. Although there was no difference regarding both SREBP-1 and PPAR-alpha. The PPAR-gamma overexpression is probably associated with high hepatic lipogenesis, causing hepatic steatosis as found in the HF-F2 offspring.

Two-way ANOVA interactions. There was a significant interaction between maternal diet and offspring generation in the following offspring data: body mass $(\mathrm{P}=$ $0.008)$, plasma triacylglycerol $(\mathrm{P}=0.007)$, total cholesterol $(\mathrm{P}<0.0001)$, liver mass $(\mathrm{P}=0.005), \operatorname{ALT}(\mathrm{P}=0.006)$ and liver steatosis $(\mathrm{P}<0.0001)$.

\section{DISCUSSION}

The present study provides new information concerning the impact of a maternal HF diet during pregnancy and lactation using a mouse model, focusing on the intergenerational effects on the body mass, glucose metabolism and hepatic steatosis in the second-generation (F2) offspring. The liver is highly susceptible to the detrimental effects of fetal overnutrition (Nathanielsz \& Hanson, 2003). Our results show that body mass, OGTT, insulinemia, plasma lipids and liver data were more altered in the F1 offspring in comparison with the F2 offspring.

Evidence both from human and animal studies suggests that fetal programming may not be limited to the directly exposed F1 but may be transmitted to subsequent generations without re-exposure (Jimenez-Chillaron et al., 2009; Drake \& Liu, 2010). These effects may be transmissible through both maternal and paternal lines (Jimenez-Chillaron et al.; Pentinat et al., 2010; Dunn \& Bale, 2011).

Murine models are widely used to address fetal programming and maternal HF feeding during pregnancy have caused diverse effects on fetal birth weight, including no effect, decreased birth weight, and increased birth weight (Buckley et al., 2005; Howie et al., 2009). The maternal obesity programs to an increased sensitivity to weight gain in the offspring in the absence of changes in birth weights (Alfaradhi et al.). We observed the HF-F1 offspring with higher BM during their lives compared to the SC-F1 offspring, but not in the F2. Another study of chronic administration a HF diet both before and during pregnancy resulted in decreased fetal birth weight in rodents, which suggests some degree of placental insufficiency (Howie et $a l$.). The present findings are in agreement with previous results of our laboratory as offspring from HF-fed mothers were smaller at birth but has a catch-up growth, showing overweight at weaning (Gregorio et al.; Bringhenti et al.; Graus-Nunes et al., 2015).

The maternal factors that cause the metabolic disorders in the offspring are unknown and hyperinsulinemia seems to play a role (Barbosa-da-Silva et al., 2014). The decline in glucose homeostasis develops with age in models of developmental programming. Offspring of obese mothers becomes hyperinsulinemic at 3 months-old, progressing to type 2 diabetes at 6 months old (Samuelsson et al., 2008). It is already described that the offspring of HF-fed mothers develops insulin resistance (Buckley et al.) and glucose intolerance in adulthood (Samuelsson et al.). The present findings confirm the alterations in both insulin and glucose metabolisms in the F1 offspring, but not in the F2 offspring.

The HF-fed mothers have been shown to cause increased levels of triacylglycerol in the maternal circulation, which may enhance the concentration across the placenta, resulting in higher transport and deposition of lipids in fetal organs (Carmody et al., 2011). In fact, increased total cholesterol, plasma, and liver triacylglycerol were found in the HF-F1 offspring, but the HF-F2 offspring seems to have been spared these alterations. Of course, the effects on subsequent generations may differ from those seen in the F1, who were exposed directly to the insult in utero (Drake et al., 2011; Dunn \& Bale). The maternal insulin resistance and $\mathrm{HF}$ diet combined showed additional effects on adiposity in the offspring early life (Carmody et al.; Barbosa-da-Silva et al.).

Offspring of obese mothers is fatter and has the risk of developing fatty liver compared with offspring of lean mothers (Bruce et al., 2009; Elahi et al., 2009). Our study demonstrated the presence of microvesicular hepatocyte steatosis in the offspring of mothers who received the $\mathrm{HF}$ diet in both F1 and F2. Liver and adipose tissue are differently affected by HF-fed mothers, leading to upregulated hepatic lipogenesis coupled with blunted lipolysis in white adipose tissue. Critical points of regulation in the respective pathways are associated with a high expression of SREBP-1c and downstream genes involved in hepatic lipid biosynthesis concomitant with reduced expression of PPAR-alpha and related genes involved in fatty acid oxidation (Shankar et al., 2010), which agrees with our results. However, the steatosis observed in F2, probably was favored hepatic lipogenesis through enhanced PPAR-gamma expression. PPAR-gamma downstream effects, including induction of SREBP-1c, are responsible for regulating the genes required for de novo lipogenesis and, consequently, increased lipid accumulation (Knebel et al., 2012). 
In conclusion, HF-fed mothers led to intergenerational effects on liver structure and metabolism, more pronounced in F1, but F2 also showed important alterations in the liver structure. We proposed that the HFfed mothers impair both lipogenesis and beta-oxidation pathways through upregulation of PPAR-gamma and downregulation of PPAR-alpha. The F2 offspring has enhanced lipogenesis, but it causes disrupted PPAR balance, favoring hepatic lipid accumulation in these animals that were not directly exposed to the mother nutrition.

\section{ACKNOWLEDGMENTS}

The authors would like to thank Mrs. Aline Penna, Mrs. Gezileia Lau, and Mrs. Michele Soares for their technical assistance. This study was supported by Conselho Nacional de Desenvolvimento Científico e Tecnológico (CNPq), Fundação de Amparo a Pesquisa do Estado do Rio de Janeiro (FAPERJ), and Coordenação de Aperfeiçoamento de Pessoal de Nível Superior (CAPES), Brazil.

LANNES, W. R.; MIRANDA, A. C.; SOUZA-MELLO, V.; BARBOSA-DA-SILVA, S.; AGUILA, M. B. \& MANDARIMDE-LACERDA, C. A. La lipogenesis hepática y la beta-oxidación están alteradas en las crías de las madres alimentadas con una dieta alta en grasas en las dos primeras generaciones ( $\mathrm{F} 1 \mathrm{y}$ F2). Int. J. Morphol., 33(4):1510-1517, 2015.

RESUMEN: Los madres alimentadas con dieta rica en grasas (HF) pueden programar una susceptibilidad al desarrollo de enfermedades crónicas en su descendencia y de este modo afectar a las generaciones posteriores. El presente estudio evaluó la estructura del hígado en la edad adulta, centrándose en las generaciones F1 y F2. Las hembras C57BL/6 (F0) fueron alimentadas con dieta estándar (CS) o dieta HF (8 semanas) antes del apareamiento y durante la gestación y lactancia para producir la generación F1 (CS-F1 y HF-F1). Todas las demás madres y crías fueron alimentadas con CS. A los 3 meses de edad, las hembras F1 fueron apareadas para producir la generación F2 (CS-F2 y HF-F2). El hígado se conservó en varios fragmentos y se preparó, por un lado, para el análisis histológico, y por otro, se lo congeló para realizar análisis bioquímicos y moleculares. La descendencia F1 y F2 se estudió a los 3 meses de edad. HFF1 tuvo una mayor masa corporal (BM) en comparación con CS-F1 ( $\mathrm{P}=0,001)$, pero no el grupo HF-F2 en comparación con CS-F2. HF-F1 tenía intolerancia a la glucosa en comparación con CS-F1, pero no el grupo HF-F2 en comparación con CSF2. HF-F1 $(\mathrm{P}=0,009)$ y HF-F2 $(\mathrm{P}=0,03)$ mostraron hiperinsulinemia en comparación con sus homólogos. Ambos grupos HF-F1 y HF-F2 mostraron más esteatosis que las contrapartes CS (F1 y F2, P <0,0001). HF-F1 mostró una mayor expresión de PPAR-gamma y SREBP1-c en comparación con el grupo CS-F1 $(\mathrm{P}=0,01)$. HF-F2 mostró aumento de la expresión de PPAR-gamma en comparación con CS-F2 $(\mathrm{P}=0,04)$. En conclusión, la madre alimentada con HF presenta ambas vías afectadas, de lipogénesis y de la beta-oxidación, en la F1 a través de la regulación positiva de PPAR-gamma y con regulación a la baja de los PPAR-alfa. En F2, solo ha mejorado la vía de lipogénesis, pero causa un desbalance de PPAR, lo que favorece la acumulación de lípidos hepáticos y la alteración del metabolismo en estos animales que no estaban directamente expuestos a la ingesta materna de HF.

PALABRAS CLAVE: Dieta alta en grasa; Lipogénesis hepática; Beta oxidación; Obesidad materna; Descendencia.

\section{REFERENCES}

Aguila, M. B.; Pinheiro, Ada. R.; Parente, L. B. \& Mandarim-deLacerda, C. A. Dietary effect of different high-fat diet on rat liver stereology. Liver Int., 23(5):363-70, 2003.

Alfaradhi, M. Z.; Fernandez-Twinn, D. S.; Martin-Gronert, M. S.; Musial, B.; Fowden, A. \& Ozanne, S. E. Oxidative stress and altered lipid homeostasis in the programming of offspring fatty liver by maternal obesity. Am. J. Physiol. Regul. Integr. Comp. Physiol., 307(1):R26-34, 2014.

Angulo, P. Obesity and nonalcoholic fatty liver disease. Nutr. Rev., 65(6 Pt. 2):S57-63, 2007.

Barbosa-da-Silva, S.; Sarmento, I. B.; Bargut, T. C. L.; Souza-Mello, V.; Aguila, M. B. \& Mandarim-de-Lacerda, C. A. Animal models of nutritional induction of type 2 diabetes mellitus. Int. J. Morphol., 32(1):279-93, 2014.

Bringhenti, I.; Ornellas, F.; Martins, M. A.; Mandarim-de-Lacerda, C. A. \& Aguila, M. B. Early hepatic insult in the offspring of obese maternal mice. Nutr. Res., 35(2):136-45, 2015.

Bruce, K. D.; Cagampang, F. R.; Argenton, M.; Zhang, J.; Ethirajan, P. L.; Burdge, G. C.; Bateman, A. C.; Clough, G. F.; Poston, L.; Hanson, M. A.; McConnell, J. M. \& Byrne, C. D. Maternal high-fat feeding primes steatohepatitis in adult mice offspring, involving mitochondrial dysfunction and altered lipogenesis gene expression. Hepatology, 50(6):1796-808, 2009.

Buckley, A. J.; Keserü, B.; Briody, J.; Thompson, M.; Ozanne, S. E. \& Thompson, C. H. Altered body composition and metabolism in the male offspring of high fat-fed rats. Metabolism, 54(4):500-7, 2005.

Carmody, J. S.; Wan, P.; Accili, D.; Zeltser, L. M. \& Leibel, R. L. Respective contributions of maternal insulin resistance and diet to metabolic and hypothalamic phenotypes of progeny. Obesity (Silver Spring), 19(3):492-9, 2011. 
LANNES, W. R.; MIRANDA, A. C.; SOUZA-MELLO, V.; BARBOSA-DA-SILVA, S.; AGUILA, M. B. \& MANDARIM-DE-LACERDA, C. A. Both hepatic lipogenesis and beta-oxidation are altered in offspring of mothers fed a high-fat diet in the first two generations (F1 and F2). Int. J. Morphol., 33(4):1510-1517, 2015.

Catta-Preta, M.; Mendonca, L. S.; Fraulob-Aquino, J.; Aguila, M. B. \& Mandarim-de-Lacerda, C. A. A critical analysis of three quantitative methods of assessment of hepatic steatosis in liver biopsies. Virchows Arch., 459(5):477-85, 2011.

Drake, A. J. \& Liu, L. Intergenerational transmission of programmed effects: public health consequences. Trends Endocrinol. Metab., 21(4):206-13, 2010.

Drake, A. J.; Liu, L.; Kerrigan, D.; Meehan, R. R. \& Seckl, J. R. Multigenerational programming in the glucocorticoid programmed rat is associated with generation-specific and parent of origin effects. Epigenetics, 6(11):1334-43, 2011.

Dunn, G. A. \& Bale, T. L. Maternal high-fat diet effects on thirdgeneration female body size via the paternal lineage. Endocrinology, 152(6):2228-36, 2011.

Elahi, M. M.; Cagampang, F. R.; Mukhtar, D.; Anthony, F. W.; Ohri, S. K. \& Hanson, M. A. Long-term maternal high-fat feeding from weaning through pregnancy and lactation predisposes offspring to hypertension, raised plasma lipids and fatty liver in mice. Brit. J. Nutr., 102(4):514-9, 2009.

Graus-Nunes, F.; Dalla Corte Frantz, E.; Lannes, W. R.; da Silva Menezes, M. C.; Mandarim-de-Lacerda, C. A. \& Souza-Mello, V. Pregestational maternal obesity impairs endocrine pancreas in male F1 and F2 progeny. Nutrition, 31(2):380-7, 2015.

Gregorio, B. M.; Souza-Mello, V.; Carvalho, J. J.; Mandarim-deLacerda, C. A. \& Aguila, M. B. Maternal high-fat intake predisposes nonalcoholic fatty liver disease in C57BL/6 offspring. Am. J. Obstet. Gynecol., 203(5):495.e1-8, 2010.

Howie, G. J.; Sloboda, D. M.; Kamal, T. \& Vickers, M. H. Maternal nutritional history predicts obesity in adult offspring independent of postnatal diet. J. Physiol., 587(Pt. 4):905-15, 2009.

Jimenez-Chillaron, J. C.; Isganaitis, E.; Charalambous, M.; Gesta, S.; Pentinat-Pelegrin, T.; Faucette, R. R.; Otis, J. P.; Chow, A.; Diaz, R.; Ferguson-Smith, A. \& Patti, M. E. Intergenerational transmission of glucose intolerance and obesity by in utero undernutrition in mice. Diabetes, 58(2):460-8, 2009.

Knebel, B.; Haas, J.; Hartwig, S.; Jacob, S.; Köllmer, C.; Nitzgen, U.; Muller-Wieland, D. \& Kotzka, J. Liver-specific expression of transcriptionally active SREBP-1c is associated with fatty liver and increased visceral fat mass. PloS One, 7(2):e31812, 2012.

Magliano, D. C.; Bargut, T. C.; de Carvalho, S. N.; Aguila, M. B.; Mandarim-de-Lacerda, C. A. \& Souza-Mello, V. Peroxisome proliferator-activated receptors-alpha and gamma are targets to treat offspring from maternal diet-induced obesity in mice. PLoS One, 8(5):e64258, 2013.

Nathanielsz, P. W. \& Hanson, M. A. The fetal dilemma: spare the brain and spoil the liver. J. Physiol., 548(Pt. 2):333, 2003
Ornellas, F.; Souza-Mello, V.; Mandarim-de-Lacerda, C. A. \& Aguila, M. B. Programming of obesity and comorbidities in the progeny: lessons from a model of diet-induced obese parents. PLoS One, 10(4):e0124737, 2015.

Pentinat, T.; Ramon-Krauel, M.; Cebria, J.; Diaz, R. \& JimenezChillaron, J. C. Transgenerational inheritance of glucose intolerance in a mouse model of neonatal overnutrition. Endocrinology, 151(12):5617-23, 2010.

Reeves, P. G.; Nielsen, F. H. \& Fahey, G. C. Jr. AIN-93 purified diets for laboratory rodents: final report of the American Institute of Nutrition ad hoc writing committee on the reformulation of the AIN-76A rodent diet. J. Nutr., 123(11):1939-51, 1993.

Samuelsson, A. M.; Matthews, P. A.; Argenton, M.; Christie, M. R.; McConnell, J. M.; Jansen, E. H.; Piersma, A. H.; Ozanne, S. E.; Twinn, D. F.; Remacle, C.; Rowlerson, A.; Poston, L. \& Taylor, P. D. Diet-induced obesity in female mice leads to offspring hyperphagia, adiposity, hypertension, and insulin resistance: a novel murine model of developmental programming. Hypertension, 51(2):383-92, 2008.

Shankar, K.; Kang, P.; Harrell, A.; Zhong, Y.; Marecki, J. C.; Ronis, M. J. \& Badger, T. M. Maternal overweight programs insulin and adiponectin signaling in the offspring. Endocrinology, 151(6):2577-89, 2010.

Wahli, W. \& Michalik, L. PPARs at the crossroads of lipid signaling and inflammation. Trends Endocrinol. Metab., 23(7):351-63, 2012 .

Yessoufou, A. \& Moutairou, K. Maternal diabetes in pregnancy: early and long-term outcomes on the offspring and the concept of "metabolic memory". Exp. Diabetes Res., 2011:218598, 2011.

\section{Correspondence to:}

Sandra Barbosa-da-Silva

Laboratório de Morfometria e Morfologia Cardiovascular

Centro Biomédico

Instituto de Biologia

Universidade do Estado do Rio de Janeiro

AV. 28 de Setembro 87 (fds) 20551-030

Rio de Janeiro, RJ

BRAZIL

Email: sandrabarbosasilva@gmail.com www.Immc.uerj.br

Received: 07-07-2015

Accepted: 08-09-2015 